\title{
Effects of Different Nanomaterials on Hardening and Performance of Ultra-High Strength Concrete (UHSC)
}

\author{
Zemei Wu ${ }^{\text {a,b }}$, Caijun Shi ${ }^{\text {a, }}$, K.H. Khayat ${ }^{\mathrm{b}}$, Shu Wan ${ }^{\mathrm{a}}$ \\ ${ }^{a}$ College of Civil Engineering, Hunan University, Changsha 410082, PR China, \\ ${ }^{b}$ Department of Civil, Architectural and Environmental Engineering, Missouri University of Science and \\ Technology, Rolla, Missouri, USA
}

Abstract: Nanomaterials have attracted much interest in cement-based materials during the past decade. In this study, the effects of different nano- $\mathrm{CaCO}_{3}$ and nano- $\mathrm{SiO}_{2}$ contents on flowability, heat of hydration, mechanical properties, phase change, and pore structure of ultra-high strength concrete (UHSC) were investigated. The dosages of nano- $\mathrm{CaCO}_{3}$ were $0,1.6 \%, 3.2 \%, 4.8 \%$, and $6.4 \%$, by the mass of cementitious materials, while the dosages of nano- $\mathrm{SiO}_{2}$ were $0,0.5 \%, 1.0 \%, 1.5 \%$, and $2 \%$. The results indicated that both nano- $\mathrm{CaCO}_{3}$ and nano- $\mathrm{SiO}_{2}$ decreased the flowability and increased the heat of hydration with the increase of their contents. The optimal dosages to enhance compressive and flexural strengths were $1.6 \%$ to $4.8 \%$ for the nano- $\mathrm{CaCO}_{3}$ and $0.5 \%$ to $1.5 \%$ for the nano- $\mathrm{SiO}_{2}$. Although compressive and flexural strengths were comparable for the two nanomaterials after $28 \mathrm{~d}$, their strength development tendencies with age were different. UHSC mixtures with nano- $\mathrm{SiO}_{2}$ showed continuous and sharp increase in strength with age up to $7 \mathrm{~d}$, while those with nano- $\mathrm{CaCO}_{3}$ showed almost constant strength between 3 and $7 \mathrm{~d}$, but sharp increase thereafter. Thermal gravimetry (TG) analysis demonstrated that the calcium hydroxide $(\mathrm{CH})$ content in UHSC samples decreased significantly with the increase of nano-SiO 2 content, but remained almost constant for those with nano- $\mathrm{CaCO}_{3}$. Mercury intrusion porosimetry (MIP) results showed that both porosity and critical pore size decreased with the increase of hydration time as well as the increase of nanoparticles content to an optimal threshold, beyond which porosity decreased. The difference between them was that nano- $\mathrm{CaCO}_{3}$ mainly reacted with $\mathrm{C}_{3} \mathrm{~A}$ to form carboaluminates, while

*Corresponding author. Tel./fax: +86 73188823937.

E-mail address: cshi@hnu.edu.cn (C. Shi) 
nano- $\mathrm{SiO}_{2}$ reacted with $\mathrm{Ca}(\mathrm{OH})_{2}$ to form $\mathrm{C}-\mathrm{S}-\mathrm{H}$. Both nano- $\mathrm{CaCO}_{3}$ and nano-SiO${ }_{2}$ demonstrated nucleation and filling effects and resulted in less porous and more homogeneous structure.

Keywords: UHSC; Nano- $\mathrm{CaCO}_{3} ; \mathrm{Nano}-\mathrm{SiO}_{2}$; Hydration; Strength; Calcium hydroxide; Pore structure

\section{Introduction}

Ultra-high strength cement based-material (UHSC) is a novel type of composite materials with superior static and dynamic mechanical properties, and excellent durability. Such material can be used in marine structures, defense and military engineering applications, and high building construction [1-3]. However, as an intrinsically heterogeneous material, the structure of cement-based materials can be generally discretized into four multi-scale phases: nano, micro, meso, and macro [4]. The macro-properties of cement-based materials are dominated by the structure at the nano-scale level. The main hydration product, C-S-H, occupies at least $60-70 \%$ by volume of the hardened cement paste. It is a nano-scale material with average diameter around $10 \mathrm{~nm}$ [5]. It is suggested that C-S-H has low, high, and ultra-high density forms with different hardness and elastic modulus values and volume fractions [4,6]. High density C-S-H degrades much slower than low density C-S-H under external environmental condition [6]. Furthermore, water loss from pores in the C-S-H gel can lead to considerable autogeneous shrinkage, which can cause cracking and loss in strength and durability of UHSC [7]. Therefore, it is vital to optimize the microstructure of cement-based materials from the nano-scale to ensure high performance.

Nanotechnology has attracted much interest over the past decade. Since the introduction of nanomaterials, extensive research has been conducted to promote their use in cement-based material. 
It is well known that nanomaterials can provide significant enhancement in performance of cement-based material given their physical effect (filling and nucleation effects) as well as the chemical reactivity [8]. Nano-silica $\left(\right.$ nano- $\mathrm{SiO}_{2}$ ) [9], nano-alumina (nano- $\mathrm{Al}_{2} \mathrm{O}_{3}$ ) [10], nano-titanium oxide (nano- $\left.\mathrm{TiO}_{2}\right)$ [11], nano- $\mathrm{CaCO}_{3}[12]$, nano iron $\left(\mathrm{Fe}_{2} \mathrm{O}_{3}\right)$, and nanotubes [13] have been studied for use in cement-based materials. Among those, nano- $\mathrm{CaCO}_{3}$ and nano- $\mathrm{SiO}_{2}$ are commonly used. This is because nano- $\mathrm{CaCO}_{3}$ is relatively cheap due to abundant supplying of $\mathrm{CaCO}_{3}$ in limestone, chalk, and marble, and nano-SiO 2 can present superior performance given its high specific area and pozzolanic activity [14]. Prototypes of limestone and silica fume have been employed in cement-based materials for many years [15-17].

Camiletti et al. [14] investigated the effects of nano- and micro-limestone on early age properties of ultra-high performance concrete (UHPC) and found that the addition of nano- and micro- limestone reduced its setting time. Moreover, the addition of $2.5 \%$ to $5 \%$ nano-limestone could lead to $32 \%$ to $75 \%$ improvement in $24 \mathrm{~h}$ compressive strength in comparison to that without any nano-limestone. Shaikh et al. [12] found that samples incorporating $1 \%$ nano-CaCO $\mathrm{C}_{3}$ particles showed the highest compressive strength for high volume fly ash concrete. Rong et al. [18] found that nano- $\mathrm{SiO}_{2}$ accelerated the hardening and enhanced mechanical properties of UHPC when $3 \%$ nano- $\mathrm{SiO}_{2}$, by mass of cementations materials, was incorporated. Ghafari et al. [19] reported that nano- $\mathrm{SiO}_{2}$ reduced the workability of UHPC and increased compressive strength, especially at early age. Although both the nano- $\mathrm{CaCO}_{3}$ and nano- $\mathrm{SiO}_{2}$ could improve mechanical properties, their hydration mechanisms, hardening processes, and age dependencies are different [20]. This could lead to different hydration products and thereby change in mechanical properties [21-23]. Furthermore, mechanical stirring and ultrasonic dispersion techniques are often adopted to avoid agglomeration of nanomaterials [24]. However, the dispersion time and speed would contribute to the experimental 
results, which are often neglected. If nanomaterials can be efficiently dispersed under normal mixing procedure, this would not only facilitate their applications in cement-based materials but also reduce energy consumption.

In order to understand the hydration mechanism and hardening process of UHSC made with either nano- $\mathrm{CaCO}_{3}$ or nano- $\mathrm{SiO}_{2}$, the flowability, heat of hydration as well as compressive and flexural strengths of UHSC mixtures with five different contents of each nanomaterial were investigated. The crystalline phases and pore structure of the samples were investigated by thermal gravimetry (TG) and mercury intrusion porosimetry (MIP), respectively. The study seeks to understand the hydration mechanisms of these types and contents of nanomaterials.

\section{Experimental program}

\subsection{Materials}

Portland cement complying with the Chinese Standard GB175-2007 was used [25]. The 3-d compressive and flexural strengths of standard mortar sample are 28.3 and 5.6 MPa, respectively. Silica fume with particle size rangeing between 0.02 and $0.28 \mu \mathrm{m}$ was used. $\mathrm{Nano}-\mathrm{CaCO}_{3}$ and nano- $\mathrm{SiO}_{2}$ were used, as shown in Fig. 1. The nano- $\mathrm{CaCO}_{3}$ has a size of about 15 to $105 \mathrm{~nm}$ with $97.8 \%$ calcite content. The nano- $\mathrm{SiO}_{2}$ has a size of 5 to $35 \mathrm{~nm}$ with $99.8 \% \mathrm{SiO}_{2}$ content. Table 1 summarizes the chemical composition and physical properties of the cementitious materials. 


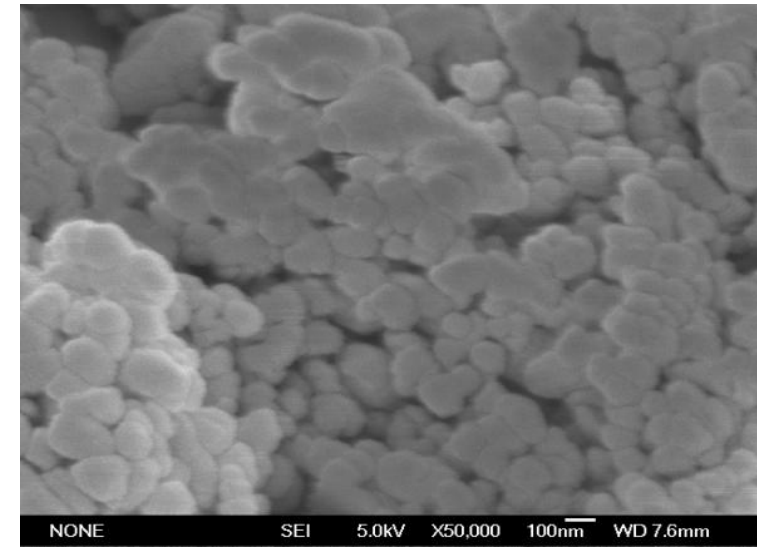

(a) Nano- $\mathrm{CaCO}_{3}$ particles [26]

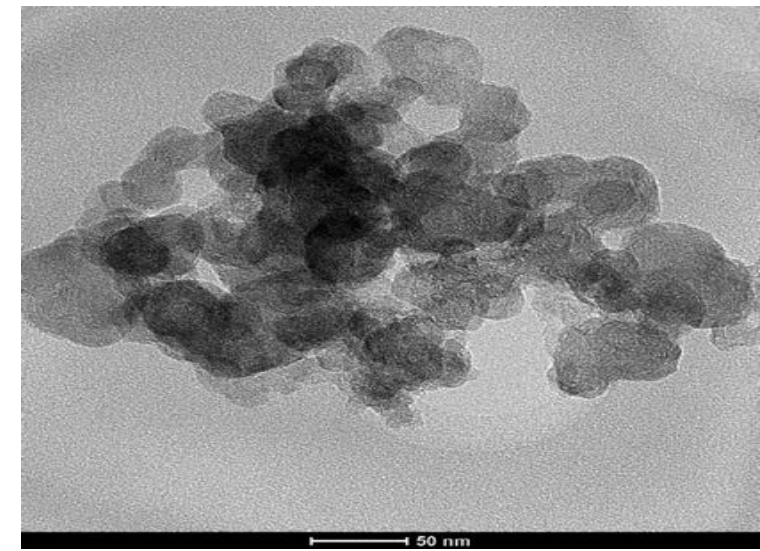

(b) Nano- $\mathrm{SiO}_{2}$ particles [18]

Fig. 1 Morphogy of nano-particles

Natural river sand with a fineness modulus of 3.0 was used. Particles with size greater than 2.36 $\mathrm{mm}$ were removed by sieving in order to enhance mechanical properties of the UHSC.

A polycarboxylate-based superplasticizer (SP) with a solid content of $20 \%$ was incorporated. Its water-reducing capacity is greater than $30 \%$. The dosage of SP in the all mixture was set to $2 \%$, by mass of cementitious materials. This dosage corresponds to a well-dispersed system for the reference mixture without any nano-material [27,28].

Table 1 Chemical composition and physical properties of cementitious materials

\begin{tabular}{|c|c|c|c|c|c|}
\hline Materials & & Cement & Silica fume & Nano- $\mathrm{CaCO}_{3}$ & $\mathrm{Nano}_{-\mathrm{SiO}_{2}}$ \\
\hline $\mathrm{SiO}_{2}(\%)$ & & 21.18 & 93.90 & - & 99.80 \\
\hline $\mathrm{Al}_{2} \mathrm{O}_{3}(\%)$ & & 4.73 & - & - & - \\
\hline $\mathrm{Fe}_{2} \mathrm{O}_{3}(\%)$ & & 3.41 & 0.59 & 0.02 & - \\
\hline $\mathrm{SO}_{3}(\%)$ & & 2.83 & - & - & - \\
\hline $\mathrm{CaO}(\%)$ & & 62.49 & 1.85 & 97.90 & - \\
\hline $\mathrm{MgO}(\%)$ & & 2.53 & 0.27 & 0.50 & - \\
\hline $\mathrm{Na}_{2} \mathrm{O}(\%)$ & & - & 0.17 & - & - \\
\hline $\mathrm{K}_{2} \mathrm{O}(\%)$ & & - & 0.86 & - & - \\
\hline Loss on ignition (\%) & & 1.20 & 0.30 & - & - \\
\hline Surface area $\left(\mathrm{m}^{2} / \mathrm{kg}\right)$ & & 350 & 18,500 & 42,000 & 160,000 \\
\hline Specific gravity $\left(\mathrm{kg} / \mathrm{m}^{3}\right)$ & & 3140 & 2200 & - & - \\
\hline Particle size $(\mathrm{nm})$ & & 36,700 & $20-280$ & $15-105$ & $5-35$ \\
\hline Setting time (min) & Initial & 172 & - & - & - \\
\hline
\end{tabular}


Final 222

Compressive strength (MPa) $\quad 3$ d $\quad 28.30$

Flexural strength $(\mathrm{MPa})$

$3 \mathrm{~d} \quad 5.60$

103

2.2. Mixture proportion and sample preparation

105

The mixture proportion of UHSC is shown in Table 2. The NC series incorporating $0,1.6 \%$,

$3.2 \%, 4.8 \%$, and $6.4 \%$ nano- $\mathrm{CaCO}_{3}$, by mass of cementitious material were designated as $\mathrm{NC} 0$,

NC1.6, NC3.2, NC4.8, and NC6.4, respectively. NS series incorporating 0, 0.5\%, 1.0\%, 1.5\%, and

$2.0 \%$ nano- $\mathrm{SiO}_{2}$ were referred to as NS0, NS0.5, NS1.0, NS1.5, and NS2.0, respectively. The mixing and curing procedure is shown in Fig. 2.

110

Table 2 Mixture proportions of UHSC

\begin{tabular}{ccccccccc}
\hline \multirow{2}{*}{ No. } & \multicolumn{7}{c}{ Mass of ingredient $\left(\mathrm{kg} / \mathrm{m}^{3}\right)$} & \\
\cline { 2 - 7 } & $\mathrm{W}$ & $\mathrm{S}$ & $\mathrm{C}$ & $\mathrm{SF}$ & $\mathrm{Nano}-\mathrm{CaCO}_{3}$ & $\mathrm{Nano}^{-\mathrm{SiO}_{2}}$ & $\mathrm{SP}$ & \\
\hline NC0/NS0 & 177 & 1079 & 863.2 & 215.8 & 0 & 0 & 21.6 & 0.18 \\
NC1.6 & 177 & 1079 & 845.9 & 215.8 & 17.3 & 0 & 21.6 & 0.18 \\
NC3.2 & 177 & 1079 & 828.7 & 215.8 & 34.5 & 0 & 21.6 & 0.18 \\
NC4.8 & 177 & 1079 & 811.4 & 215.8 & 51.8 & 0 & 21.6 & 0.18 \\
NC6.4 & 177 & 1079 & 794.1 & 215.8 & 69.1 & 0 & 21.6 & 0.18 \\
NS0.5 & 177 & 1079 & 857.8 & 215.8 & 0 & 5.4 & 21.6 & 0.18 \\
NS1.0 & 177 & 1079 & 852.4 & 215.8 & 0 & 10.8 & 21.6 & 0.18 \\
NS1.5 & 177 & 1079 & 847.0 & 215.8 & 0 & 16.2 & 21.6 & 0.18 \\
NS2.0 & 177 & 1079 & 841.6 & 215.8 & 0 & 21.6 & 21.6 & 0.18 \\
\hline
\end{tabular}

\begin{tabular}{|c|c|c|c|}
\hline $\begin{array}{l}\text { All components dry } \\
\text { mixed for } 3 \mathrm{~min}\end{array}$ & $\begin{array}{l}\text { Add water and } \\
\text { SP slowly }\end{array}$ & $\begin{array}{l}\text { Mix for } 6 \mathrm{~min} \\
\text { at low speed }\end{array}$ & $\begin{array}{l}\text { Mix for } 1 \mathrm{~min} \\
\text { at high speed }\end{array}$ \\
\hline $\begin{array}{l}\text { Demou } \\
\text { lime-sa } \\
\text { until 1, }\end{array}$ & $\begin{array}{l}\text { cure in } \\
\text { water at } 20^{\circ} \mathrm{C} \\
\text {, and } 91 \mathrm{~d}\end{array}$ & $\begin{array}{l}\text { Standard curing } \\
\text { for } 24 \text { h } 20^{\circ} \mathrm{C} \\
\text { and } \mathrm{RH}>90 \%\end{array}$ & $\begin{array}{l}\text { Cast and } \\
\text { compacted }\end{array}$ \\
\hline
\end{tabular}

2.3. Experimental methods 


\subsubsection{Flowability}

The fresh UHSC mixtures were used to cast into a conical mold in the form of a frustum, as described in Chinese Standard GB2419-2005 [29]. The mini cone has an upper diameter of $70 \mathrm{~mm}$, a lower diameter of $100 \mathrm{~mm}$, and a height of $60 \mathrm{~mm}$. After cone removed, the UHSC subjected to 25 jolting cycles on the flow table. Two diameters perpendicular to each other were determined. The mean values of two measurements were recorded as the mini slump flow. mean values were reported. mixture proportion and sample preparation as described above, the cementitious material, water, and calorimeter for $3 \mathrm{~d}$. This equipment consists of a twin-instrument with one sample and one reference. The calorimeter was set to a temperature of $20^{\circ} \mathrm{C}$. 


\subsubsection{Thermal gravimetry (TG)/Derivative thermal gravimetry (DTG) analyses}

TG/DTG analyses were used to quantitatively determine the hydration products using a Netzsch STA 409 PC equipment. The tested powder samples, weighing up to $10 \mathrm{mg}$, were heated from 0 to $1000^{\circ} \mathrm{C}$ in a nitrogen atmosphere at a heating rate of $10^{\circ} \mathrm{C} / \mathrm{min}$. The proportion of $\mathrm{CH}$ to the residual mass at $1000^{\circ} \mathrm{C}$ was then calculated.

\subsubsection{Pore structure measurement}

Mercury intrusion porosimetry (MIP) is based on the principle that mercury, a typical non-wetting liquid, can only intrude a porous material if a certain pressure is applied on the measured samples. The samples were broken into 3.5 to $5.0 \mathrm{~mm}$ pieces and soaked in acetone to stop further hydration. Then they were dried at $60^{\circ} \mathrm{C}$ in oven for $24 \mathrm{~h}$ before examination. The experiments were carried out under low pressure of $0.28 \mathrm{MPa}$ and high pressure of $413.70 \mathrm{MPa}$, respectively. A glass tube with the specimen and mercury in was subsequently placed in a low and high pressure analysis port. Full-scan auto mode was selected with contacted angle and surface tension of $140^{\circ}$ and $480 \mathrm{mN} / \mathrm{m}$, respectively. The intrusion mercury volume was recorded at each pressure point.

\section{Results and discussion}

3.1. Effects of nano- $\mathrm{CaCO}_{3}$ and nano- $\mathrm{SiO}_{2}$ contents on flowability of UHSC

The effects of nano- $\mathrm{CaCO}_{3}$ and nano-SiO $\mathrm{S}_{2}$ contents on mini slump flow of UHSC mixtures are illustrated in Fig. 3. It can be seen that the slump flow gradually decreased with the increase of nano- $\mathrm{CaCO}_{3}$ and nano- $\mathrm{SiO}_{2}$ contents. The mini slump flow of the control mixture (NC0) was 220 $\mathrm{mm}$. It decreased to 160 and $155 \mathrm{~mm}$, respectively, when either $6.4 \%$ nano- $\mathrm{CaCO}_{3}$ or $2 \%$ nano-SiO 
was incorporated. This indicated that the addition of nanomaterials had a significant effect on the required water demand of UHSC mixtures. In addition, the flowability for NC series was more favorable than that of NS series at the same dosage. The mini slump flow of the NC6.4 mixture was equivalent to that of the NS2.0 mixture. This might be attributed to different particle size and specific area. Nano- $\mathrm{CaCO}_{3}$ possessed an average size of about $60 \mathrm{~nm}$ and surface area of $4.2 \times 10^{4} \mathrm{~m}^{2} / \mathrm{kg}$, while the corresponding values for nano- $\mathrm{SiO}_{2}$ were $20 \mathrm{~nm}$ and $1.6 \times 10^{5} \mathrm{~m}^{2} / \mathrm{kg}$, respectively. It is well known that the water demand of cement-based materials mainly includes two aspects: (1) filling water in the pore space between the particles; (2) adsorbed water on the surface of particle [30]. Although nanomaterials can fill voids between cement particles to replace some of entrapped water, consequently increase the amount of free water. More free water and superplasticizer would be adsorbed onto the surface of nanomaterials due to their high surface area, leading to decreased free water content and thus increasing the water demand. The latter one is the dominated factor for the decrease of flowability.

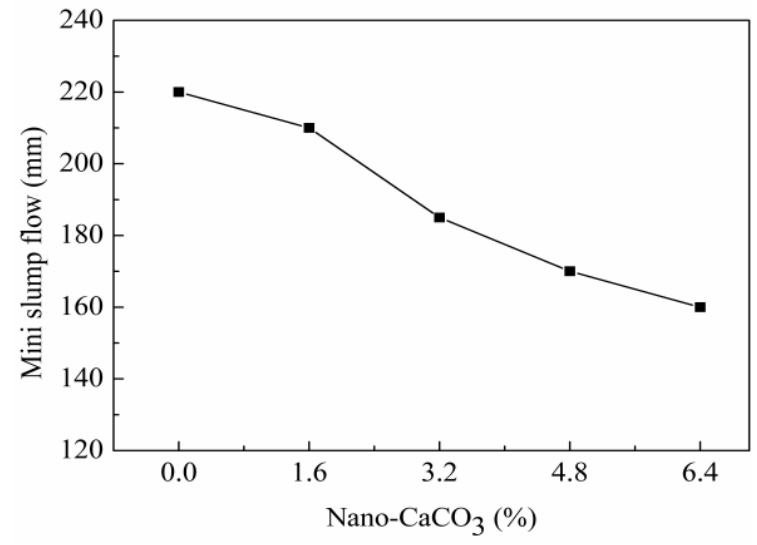

(a) Nano- $\mathrm{CaCO}_{3}$

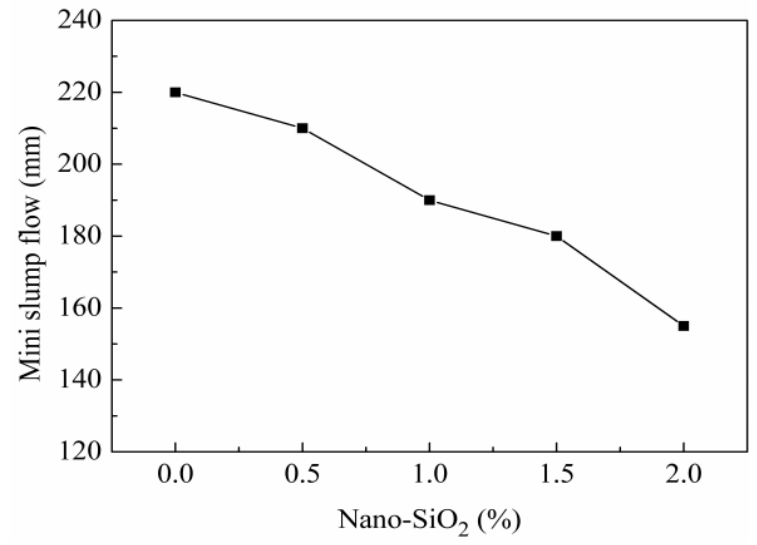

(b) $\mathrm{Nano}-\mathrm{SiO}_{2}$

Fig. 3 Mini slump flow of UHSC with different nano- $\mathrm{CaCO}_{3}$ and nano- $\mathrm{SiO}_{2}$ contents 

cementitious materials in UHSC. The addition of nanomaterials not only shortened the dormant period but also lead to an early appearance of the second peak. As seen in Fig. 4(a), the dormant period of the $\mathrm{NCO}$ mixture was around $13 \mathrm{~h}$, the addition of nano- $\mathrm{CaCO}_{3}$ reduced it to about $9 \mathrm{~h}$. This can be considered as a result of filling and chemical effects induced by nano- $\mathrm{CaCO}_{3}$ [31]. Due to its small size, nano- $\mathrm{CaCO}_{3}$ particles act as nucleation seeds. When in contact with water, the $\mathrm{Ca}^{2+}$ that rapidly released from $\mathrm{C}_{3} \mathrm{~S}$ particles is absorbed onto the surface of nano- $\mathrm{CaCO}_{3}$ particles. This 186 would decrease the concentration of $\mathrm{Ca}^{2+}$ around $\mathrm{C}_{3} \mathrm{~S}$ and consequently increase the rate and amount of hydration. Besides, $\mathrm{CO}_{3}{ }^{2-}$ can react with $\mathrm{C}_{3} \mathrm{~A}$ to form carboaluminates. Carboaluminates is a substance with high permeability in fresh state, which makes ions and water diffuse into internal structure more easily, so as to reduce the concentration of $\mathrm{Ca}^{2+}$, and thus accelerating the hydration rate [32]. However, it should be noted that the NC4.8 mixture had an earlier and higher heat of hydration than that of the NC6.4 mixture. This might be due to dilution effect associated with nano- $\mathrm{CaCO}_{3}$ when it was used as a substitution of cement. Camiletti et al. [14] reported that replacing cement with nano/micro- $\mathrm{CaCO}_{3}$ can induce a cement dilution effect in addition to a filling and a nucleation effect. When increasing the micro- $\mathrm{CaCO}_{3}$ content to a certain content, the dilution effect could dominate the interaction. This can reduce the heat of hydration, leading to a longer setting time. For nano-SiO 2 , except its filling effect, it can function as nucleation seed for the precipitation of C-S-H. This accelerating effect is well reported in publication [9]. 


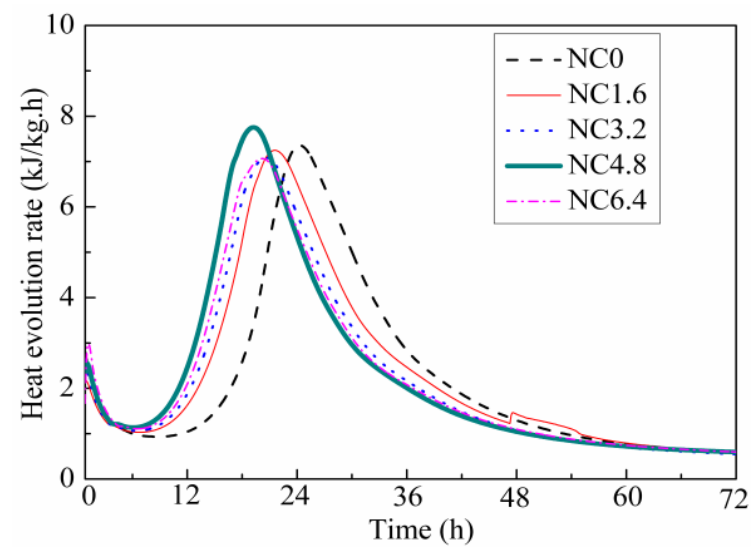

(a) nano- $\mathrm{CaCO}_{3}$

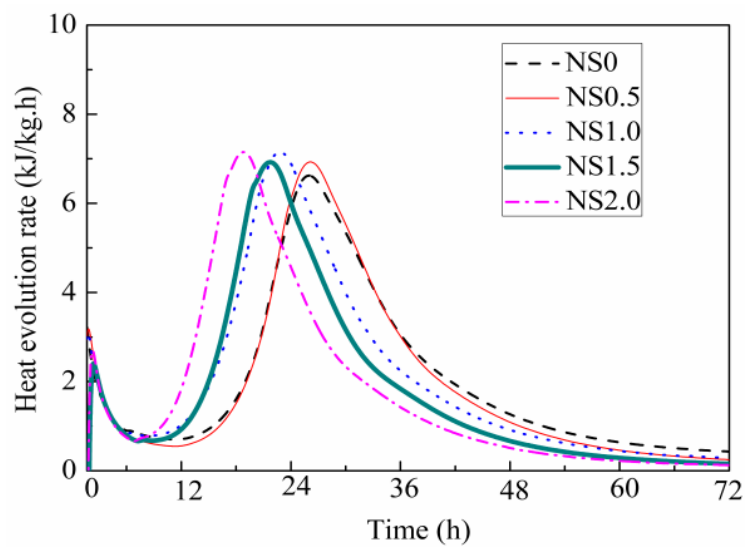

(b) nano- $\mathrm{SiO}_{2}$

Fig. 4 Effects of nano-CaCO 3 and nano-SiO 2 contents on heat evolution rate of UHSC

3.3. Effects of nano- $\mathrm{CaCO}_{3}$ and nano- $\mathrm{SiO}_{2}$ contents on compressive and flexural strengths of UHSC The influence of nano- $\mathrm{CaCO}_{3}$ on compressive and flexural strengths of UHSC at different ages is shown in Fig. 5. It can be observed that there existed an optimal dosage for the strength of UHSC. When the dosage of nano- $\mathrm{CaCO}_{3}$ content was in the range from $1.6 \%$ to $4.8 \%$, both the compressive and flexural strengths were $13 \%$ to $20 \%$ and $15 \%$ to $30 \%$ larger than that of the control sample (NC0). However, when the dosage was increased further to $6.4 \%$, the strengths decreased significantly. In most cases, the compressive and flexural strengths of the NC6.4 were even lower than those of the NC0. For example, the compressive and flexural strengths of the NC6.4 were 113 and 20.9 $\mathrm{MPa}$ at $91 \mathrm{~d}$, while the corresponding strengths for the NC0 were 120 and $22 \mathrm{MPa}$, respectively. Limestone can react with $\mathrm{C}_{3} \mathrm{~A}$ to form mono-carbonate, which is a substance with special framework with strong hydrogen bonds between oxygen atoms and interlayer waters in carbonate groups [33]. It is also said that $\mathrm{CaCO}_{3}$ could affect the nature and stability of the AFm phase [34]. However, higher nano- $\mathrm{CaCO}_{3}$ content $(6.4 \%)$ showed negative effect on strengths of UHSC. This could be attributed to the unsufficient available space for hydration products to form. Also, the superabundant amount of nano- $\mathrm{CaCO}_{3}$ would result in difficulty in uniform dispersion. 
Weerdt et al. [32] claimed that $5 \%$ limestone powder, by mass of total cementious material, had a beneficial effect on the compressive strength of conventional concrete.

Figure 5 also shows that the compressive and flexural strengths of NC series increased with age.

The compressive and flexural strengths of UHSC samples were around 40 and $9 \mathrm{MPa}$ at $1 \mathrm{~d}$,

strengths were almost constant.

225

226

227

228

229

230

231

232

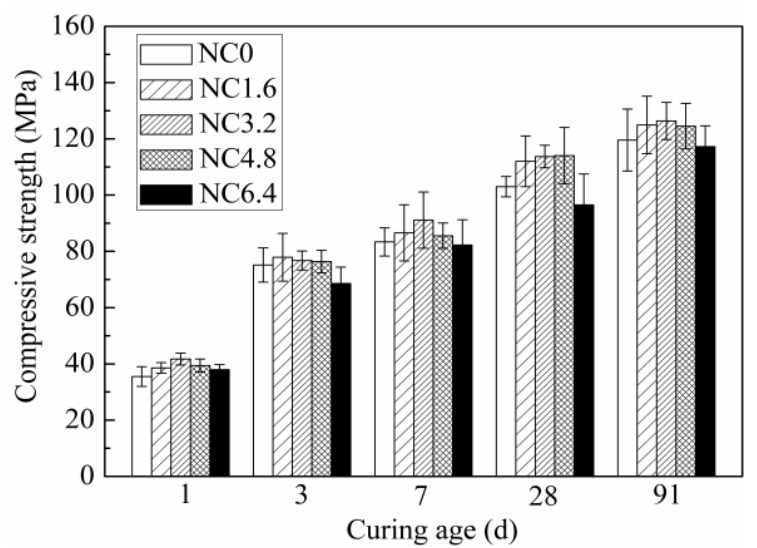

(a) Compressive strength

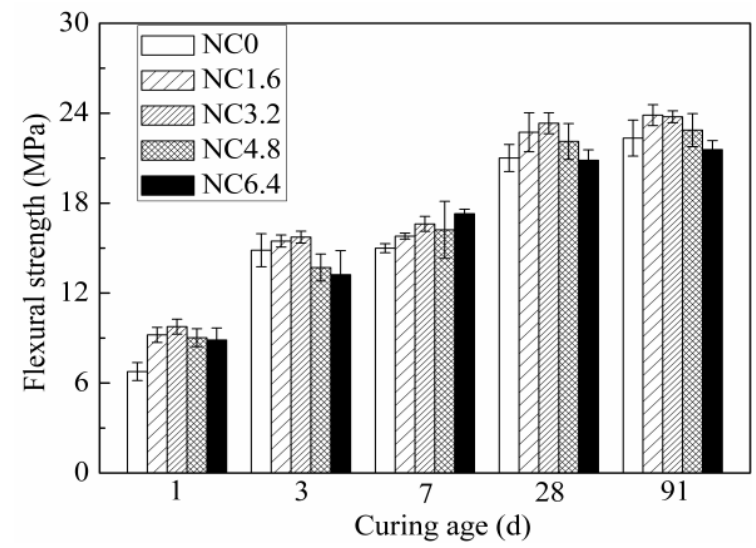

(b) Flexural strength

Fig. 5 Effects of nano- $\mathrm{CaCO}_{3}$ contents on compressive and flexural strengths of UHSC

Figure 6 depicts the compressive and flexural strengths of UHSC with different nano- $\mathrm{SiO}_{2}$ contents. It is obvious that like NC series, NS series also existed an optimal dosage, which was in the range of $0.5 \%$ to $1.5 \%$. UHSC mixtures with those dosages of nano- $\mathrm{SiO}_{2}$ increased the compressive and flexural strengths by 5-15 and 1-3 MPa, respectively, when compared to reference samples. This was comparable to the results reported by Rong et al. [18], who adopted sonication to prepared ultra-high performance cementitious composites $(\mathrm{w} / \mathrm{b}=0.2)$ with addition of $1 \%, 3 \%$, and $5 \%$ nano- $\mathrm{SiO}_{2}$. However, superfluous nano- $\mathrm{SiO}_{2}$ content of $2 \%$ reduced strength to a value lower than 
that of the reference sample. This was associated with the introduction of pores caused by

237

238 agglomeration of nano- $\mathrm{SiO}_{2}$ and reduced followability of the mixture at high nano- $\mathrm{SiO}_{2}$ concentration $[19,39]$. This indicated that appropriate addition of nano- $\mathrm{SiO}_{2}$ particles can be well dispersed by using normal mixing procedure in this study.

Compared with the NC series, UHSC mixtures with nano- $\mathrm{SiO}_{2}$ showed larger strengths than that with nano- $\mathrm{CaCO}_{3}$ did at 1,3 , and $7 \mathrm{~d}$. The compressive and flexural strengths were 85 and 16 MPa for the NC series, while 100 and $21 \mathrm{MPa}$ for the NS series at $7 \mathrm{~d}$. Besides, the strengths increase was about $10 \%$ only for the NS series, whereas $30 \%$ to $50 \%$ for the NC series from $7 \mathrm{~d}$ to 28 d. However, their strengths were comparable at 28 and $91 \mathrm{~d}$.

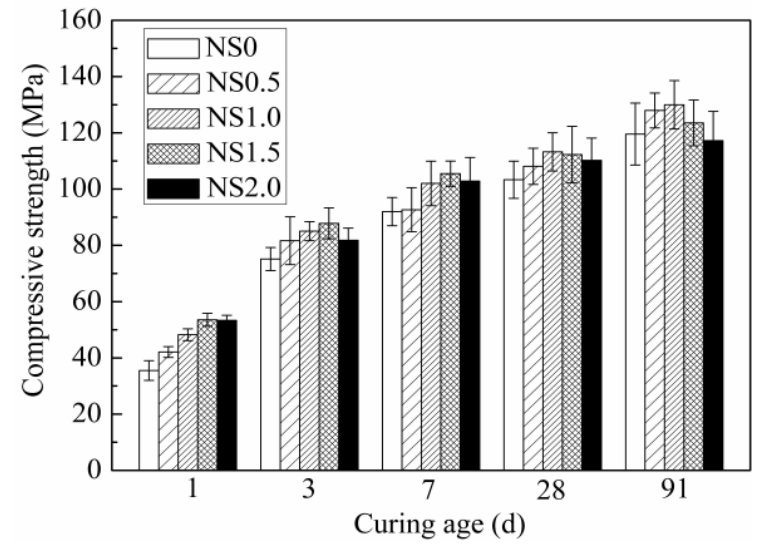

(a) Compressive strength

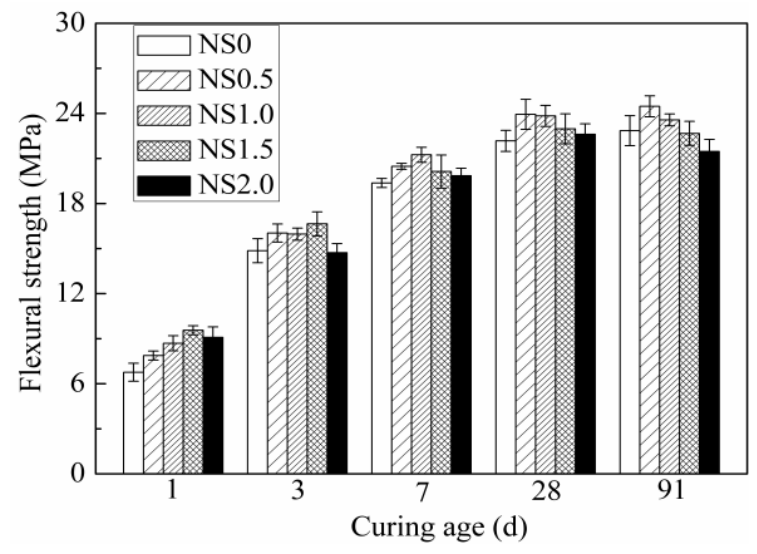

(b) Flexural strength

$$
\text { Fig. } 6 \text { Effects of different nano- } \mathrm{SiO}_{2} \text { contents on compressive and flexural strengths of UHSC }
$$

\subsection{TG/DTG analysis}

Figure 7 shows the TG and DTG curves of UHSC mixtures with different nano- $\mathrm{CaCO}_{3}$ contents at $28 \mathrm{~d}$. The hydration products in the hardened concrete are calcium silicate hydrate (C-S-H) with endothemal peak at approximately $80-90^{\circ} \mathrm{C}$, ettringite with endothemal peak around $130^{\circ} \mathrm{C}$, calcium hydroxide $(\mathrm{CH})$ with an endothemal peak in the range of $450-550^{\circ} \mathrm{C}$, and calcium carbonate with endothemal peak in the range of $600-700^{\circ} \mathrm{C}$. The endothermal peaks at the four temperature ranges 
are due to the dehydration of $\mathrm{C}-\mathrm{S}-\mathrm{H}$ and ettringite, decomposition of $\mathrm{CH}$ and $\mathrm{CaCO}_{3}$, respectively. It can be seen from Fig. 7(b), at the first temperature range of $50-150^{\circ} \mathrm{C}$, not only the endothermal peak intensity but also the covered range increased with the increase of nano- $\mathrm{CaCO}_{3}$ content. At $450-550^{\circ} \mathrm{C}$, there was no obvious change for the samples with and without nano- $\mathrm{CaCO}_{3}$. As the temperature increased to $600-700^{\circ} \mathrm{C}$, the decomposition of $\mathrm{CaCO}_{3}$ increased with the increase of nano- $\mathrm{CaCO}_{3}$ content, which suggested a larger amount of nano- $\mathrm{CaCO}_{3}$ acted as filler in UHSC. It should be noted the curve change for UHSC with high dosage of nano- $\mathrm{CaCO}_{3}(4.8 \%$ to $6.4 \%)$ was smoother than with low dosage of nano- $\mathrm{CaCO}_{3}$. This might be attributed to the sufficient and/or well-crystallized $\mathrm{CaCO}_{3}$ from incorporated nano- $\mathrm{CaCO}_{3}$ particles.

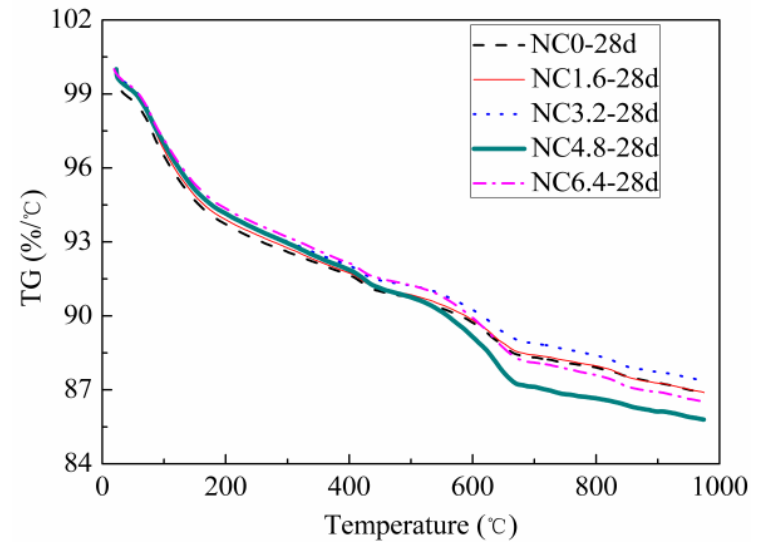

(a) TG curves

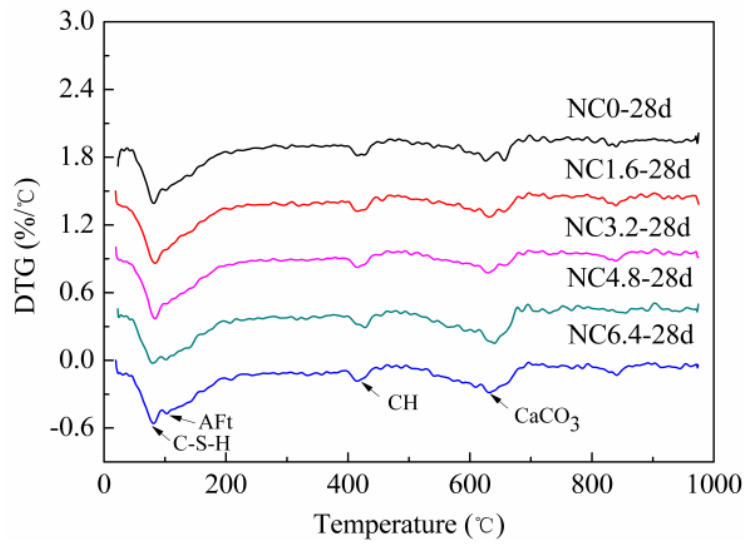

(b) DTG curves

Fig. $7 \mathrm{TG}$ and DTG curves of UHSC with different nano- $\mathrm{CaCO}_{3}$ contents at $28 \mathrm{~d}$

Figure 8 shows the TG and DTG curves of the NC3.2 at 1, 3, 7, and $28 \mathrm{~d}$. No significant difference between the DTG curves for UHSC samples can be found at 1, 3, and $7 \mathrm{~d}$. All mixtures exhibited a strong $\mathrm{AFt}$ peak at $130^{\circ} \mathrm{C}$ without obvious $\mathrm{C}-\mathrm{S}-\mathrm{H}$ peak. However, when the age reached to $28 \mathrm{~d}$, significant peak with strong intensity corresponding to $\mathrm{C}-\mathrm{S}-\mathrm{H}$ appeared. Moreover, the intensity of endothermal peak of $\mathrm{CaCO}_{3}$ decreased. This suggests increased C-S-H content and 
decreased $\mathrm{CaCO}_{3}$ content as curing age prolonged to $28 \mathrm{~d}$. It indicated that in the presence of $\mathrm{CaCO}_{3}$, mono-carbonate and/or hemi-carbonate could be formed through reacting with $\mathrm{C}_{3} \mathrm{~A}$. Limestone could also interact with the AFm and AFt phases. Weerdt et al. [21] stated that when limestone was incorporated, a peak of mono-carbonate (MC) or hemi-carbonate (HC) would appear at around $175^{\circ} \mathrm{C}$. This agrees well with that significant strength increase from 7 to $28 \mathrm{~d}$. The formation of $\mathrm{C}-\mathrm{S}-\mathrm{H}$ may be first due to the pozzolannic reaction between silica fume and $\mathrm{CH}$. The incorporation of nano- $\mathrm{CaCO}_{3}$ could combine with $\mathrm{C}-\mathrm{S}-\mathrm{H}$ to form a new compound with space network structure, optimizing the internal structure and consequently improving the mechanical properties of cement-based materials [26].

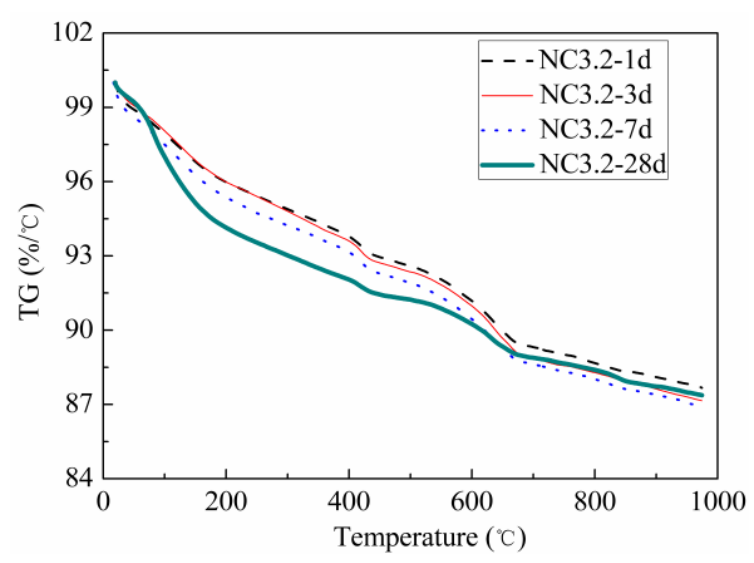

(a) TG curves of NC3.2

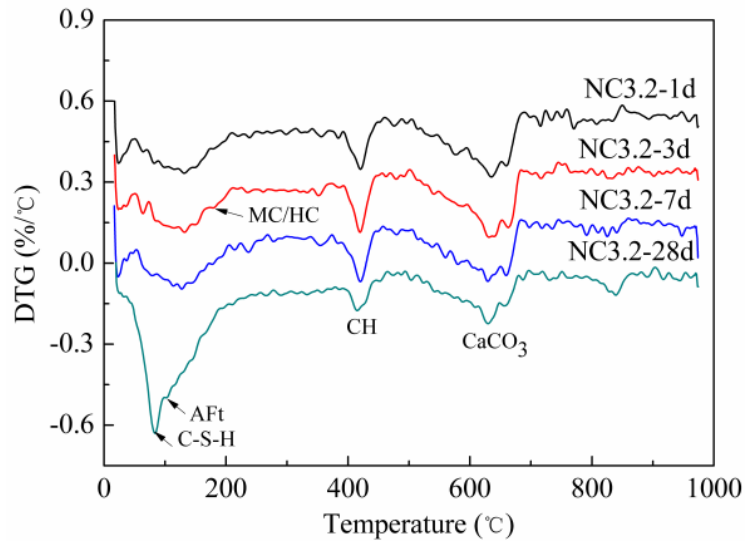

(b) DTG curves of NC3.2

Fig. 8 TG and DTG curves of NS3.2 at different ages

Figure 9 shows the TG and DTG curves of UHSC mixtures with different nano-SiO 2 contents at $28 \mathrm{~d}$. It can be seen that all the five UHSC mixtures had three significant peaks at around 80, 110, and $150^{\circ} \mathrm{C}$. The $\mathrm{C}-\mathrm{S}-\mathrm{H}$ contains absorbed water as well as interlayer water with different endothermal peaks. The first peak corresponds to the dehydration of $1.4 \mathrm{~nm}$ tobermorite, which is in the range of $80-90^{\circ} \mathrm{C}$. The second peak corresponds to the dehydration of $1.1 \mathrm{~nm}$ tobermorite at around $135-150^{\circ} \mathrm{C}[35]$. The two effects are caused by the removal of loosely bond water and firmly 
291

292

293

294

295

296

297

298

299

300

301

302

303

held water from C-S-H gel, respectively. It has indicated that $1.4 \mathrm{~nm}$ tobermorite has a single chain structure of silicate anion, while $1.1 \mathrm{~nm}$ tobermorite has structure of silicate anion with a double chain [36]. The latter is favorable for the strength of cement-based materials. As can be seen from Fig. 9(b), in the range of $30-200^{\circ} \mathrm{C}$, the surrounded area of samples with high nano- $\mathrm{SiO}_{2}$ content was broader than that with low content. Besides, the $\mathrm{CH}$ content presented a decreasing tendency with increasing nano- $\mathrm{SiO}_{2}$ content. All these were good implication of pozzolannic reaction between $\mathrm{CH}$ and nano- $\mathrm{SiO}_{2}$.

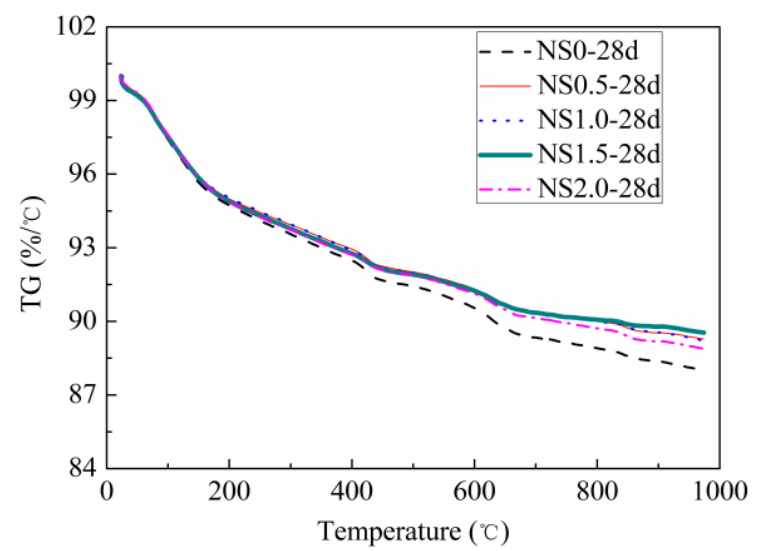

(a) TG curves

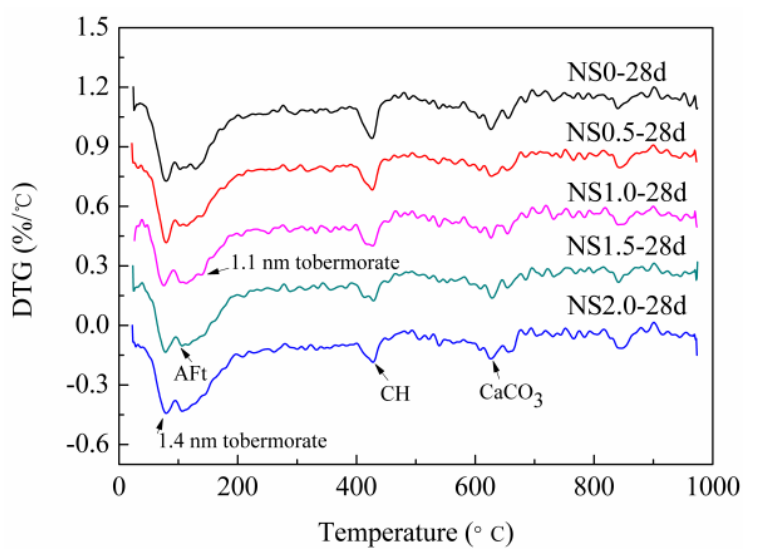

(b) DTG curves

Fig. 9 TG and DTG curves of UHSC with different nano-SiO $\mathrm{S}_{2}$ contents at $28 \mathrm{~d}$

Figure 10 presents the TG and DTG curves of the NS1.0 at age of 1, 3, 7, and $28 \mathrm{~d}$. As it can be seen, the intensity of $\mathrm{C}-\mathrm{S}-\mathrm{H}$ peak at $135-150^{\circ} \mathrm{C}$ increased obviously from 1 to $3 \mathrm{~d}$, indicating accelerated hydration rate derived from the pozzolanic reaction. At $28 \mathrm{~d}$, the intensity of C-S-H peak at $135-150^{\circ} \mathrm{C}$ was almost equal to that at $80-90^{\circ} \mathrm{C}$. This suggests optimization of $\mathrm{C}-\mathrm{S}-\mathrm{H}$ structure with curing time. Besides, it can be also found that the peak in the range of $600-730^{\circ} \mathrm{C}$ on $\mathrm{DTG}$ curves was irregular. This suggests that the formed $\mathrm{CaCO}_{3}$ in $\mathrm{UHSC}$ containing nano-SiO 2 is poor crystallized one, which may be originated from carbonation of hydration products during samples 


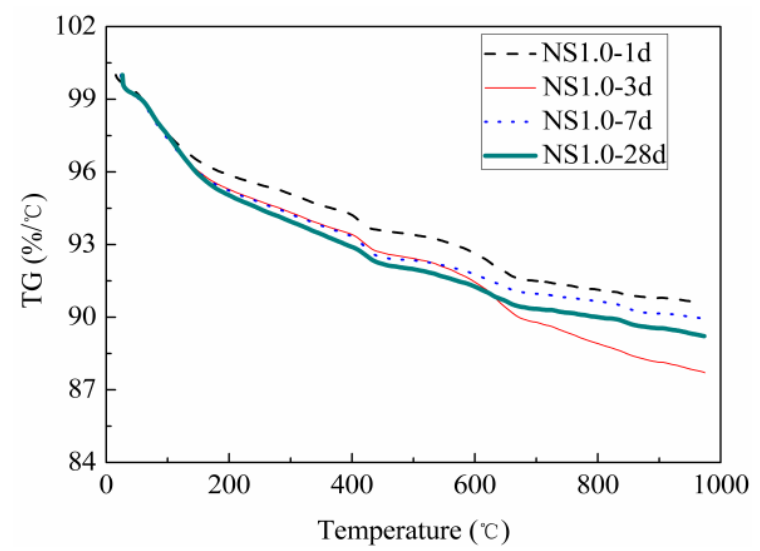

(a) TG curves of NS1.0

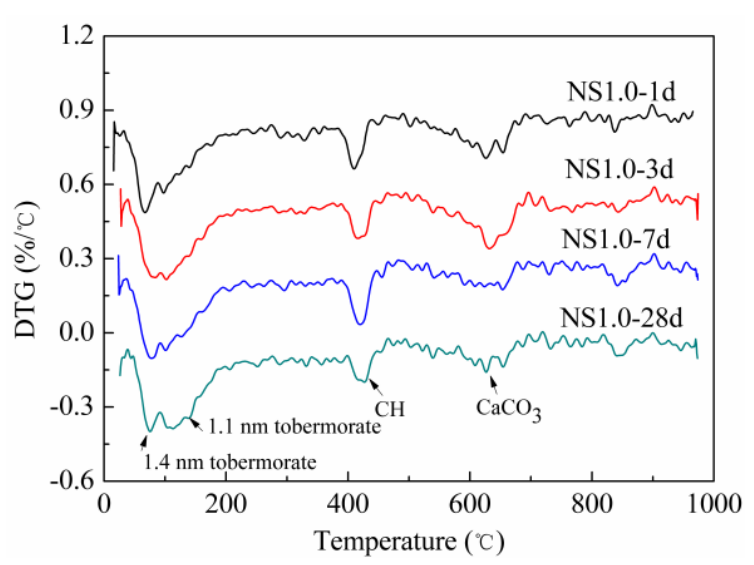

(b) DTG curves of NS1.0

\section{5. $\mathrm{CH}$ content}

The determination of the $\mathrm{CH}$ content in concrete samples is an effective method to follow the degree of hydration as a function of time. Figure 11 compares the relative amounts of $\mathrm{CH}$ formed in

317 the NC and NS series with age. It can be seen that the $\mathrm{CH}$ content in both NC and NS series decreased with age. The $\mathrm{CH}$ content in UHSC samples at 1, 3, and $7 \mathrm{~d}$ was hardly changed, however,

319 it decreased significantly from 7 to $28 \mathrm{~d}$. Besides, it is apparent that the general trend of the curves 320 for UHSC with different nano- $\mathrm{CaCO}_{3}$ contents was different from that with nano- $\mathrm{SiO}_{2}$. The $\mathrm{CH}$ content in the $\mathrm{NC}$ series was not significantly changed with the increased nano- $\mathrm{CaCO}_{3}$ content. On the other hand, a remarkable decrease in the $\mathrm{CH}$ content for the NS series was observed. This reflects the different hydration mechanisms of the nano- $\mathrm{CaCO}_{3}$ and nano- $\mathrm{SiO}_{2}$. 


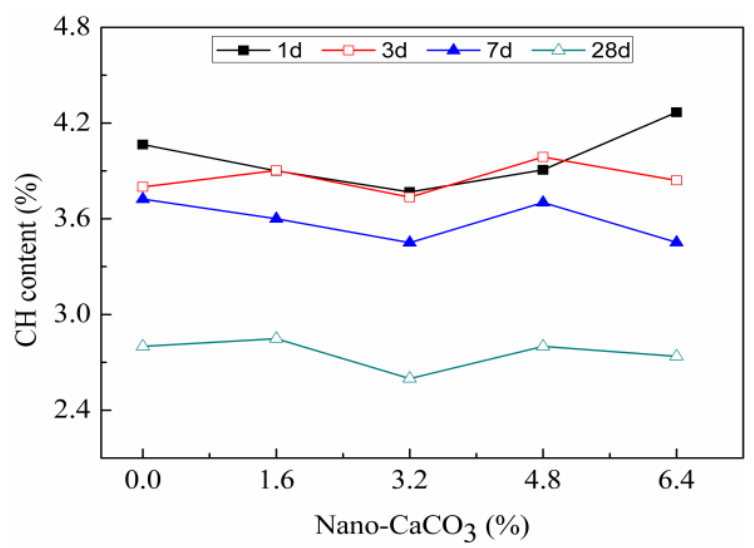

(a) $\mathrm{Nano}-\mathrm{CaCO}_{3}$

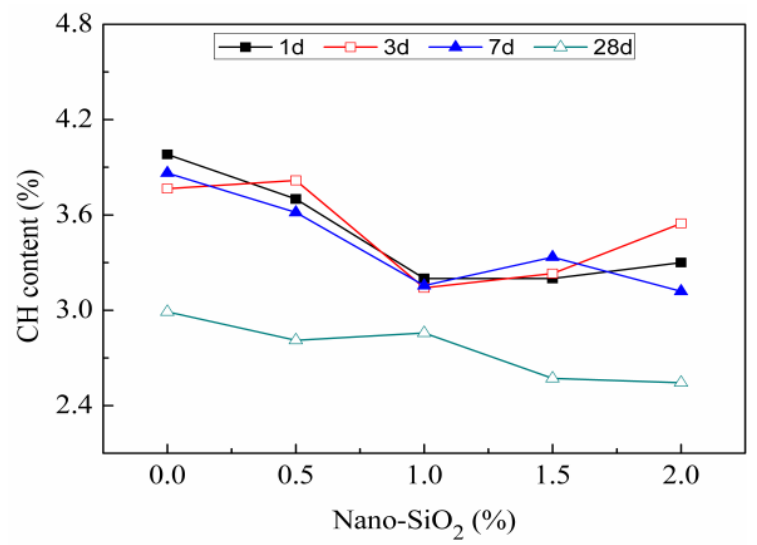

(b) $\mathrm{Nano}-\mathrm{SiO}_{2}$

Fig. 11 Amount of $\mathrm{CH}$ formed in UHSC samples with age

In the NS series, the main hydration reaction that correlates to nano- $\mathrm{SiO}_{2}$ is pozzolanic reaction with $\mathrm{CH}$, as shown in Equation (1). In $\mathrm{NC}$ series, nano- $\mathrm{CaCO}_{3}$ mainly reacts with $\mathrm{C}_{3} \mathrm{~A}$ to form carboaluminates, as shown in Equations (2) and (3). Several researchers have demonstrated that limestone does not show pozzolanic properties to produce C-S-H gel [22]. This corresponds to the limited change of $\mathrm{CH}$ in UHSC samples made with different nano- $\mathrm{CaCO}_{3}$ contents. However, the incorporation of nano- $\mathrm{CaCO}_{3}$ can change the $\mathrm{C}-\mathrm{S}-\mathrm{H}$ structure, such as the $\mathrm{Ca} / \mathrm{Si}$ ratio, and thus affecting mechanical properties of UHSC sample [37]. lower than that in the NC series before $7 \mathrm{~d}$, but it was comparable at $28 \mathrm{~d}$. The addition of $20 \%$ silica

340 fume seems to be sufficient for the pozzolanic reaction in UHSC. However, the incorporation of nano- $\mathrm{SiO}_{2}$ can alter the consumption rate of $\mathrm{CH}$ to form $\mathrm{C}-\mathrm{S}-\mathrm{H}$ due to its much greater specific 
surface $\left(160,000 \mathrm{~m}^{2} / \mathrm{kg}\right)$ than that of silica fume. Moreover, nano-SiO${ }_{2}$ has many unsaturated bonds of $\equiv \mathrm{Si}-\mathrm{O}-$ and $\equiv \mathrm{Si}$ - on the surface. These would lead to different hydration reaction, as follows [38]:

For silica fume,

$$
\begin{gathered}
\equiv \mathrm{Si}-\mathrm{O}-\mathrm{Si} \equiv+\mathrm{H}-\mathrm{OH} \rightarrow \equiv \mathrm{Si}-\mathrm{OH} \text { (react slowly) } \\
\equiv \mathrm{Si}-\mathrm{OH}+\mathrm{Ca}(\mathrm{OH})_{2} \rightarrow \mathrm{C}-\mathrm{S}-\mathrm{H}
\end{gathered}
$$

For nano- $\mathrm{SiO}_{2}$,

$$
\begin{gathered}
\equiv \text { Si-O- }+\mathrm{H}-\mathrm{OH} \rightarrow \equiv \mathrm{Si}-\mathrm{OH} \text { (react quickly) } \\
\equiv \mathrm{Si}-+\mathrm{OH}-\rightarrow \equiv \mathrm{Si}-\mathrm{OH} \text { (react quickly) } \\
\equiv \mathrm{Si}-\mathrm{OH}+\mathrm{Ca}(\mathrm{OH})_{2} \rightarrow \mathrm{C}-\mathrm{S}-\mathrm{H}
\end{gathered}
$$

The reaction rate for silica fume at the first step (Eq. 4) is slower than that (Eq. 6) for nano-SiO 2 [38]. Therefore, nano- $\mathrm{SiO}_{2}$ can accelerate the hydration and hardening process of UHSC.

\subsection{Pore structure}

Figure 12 shows the porosity and pore size distribution of UHSC containing different nano- $\mathrm{CaCO}_{3}$ contents at $28 \mathrm{~d}$. It can be seen from Fig. 12(a), within a specified dosage of $3.2 \%$, the total porosity decreased with the increase of nano- $\mathrm{CaCO}_{3}$ content. With further increase in dosage, the porosity began to increase. When the nano- $\mathrm{CaCO}_{3}$ content increased from 0 to $3.2 \%$, the porosity decreased from $15.2 \%$ to $12.5 \%$. However, with the nano- $\mathrm{CaCO}_{3}$ content increased further from $3.2 \%$ to $6.4 \%$, the porosity increased from $12.5 \%$ to $17.5 \%$. Although nano- $\mathrm{CaCO}_{3}$ can efficiently fill internal pores of the hydrated cement paste, high content of such nanoparticles can lead to agglomeration and reduction in flowability and increase in viscosity [39].

For the pore size distribution shown in Fig. 12 (b), the dv/dlog (d) curves of the five UHSC mixtures were superposed covering pore size from 40 to $1000 \mathrm{~nm}$. For pore size smaller than $40 \mathrm{~nm}$, 
the curves for UHSC containing nano- $\mathrm{CaCO}_{3}$ shifted to left indicating finer pores when compared to the $\mathrm{NC} 0$ reference sample without any nano- $\mathrm{CaCO}_{3}$. Furthermore, the peak value, i.e. inflection point on the dv/dlog (d) curve, corresponding to critical pore size decreased. This peak value corresponds to capillary pores, which has great influence on the permeability of concrete [40]. It also reflects the connectivity of the pores and tortuosity of penetration path in concrete. The results indicated that the addition of appropriate nano- $\mathrm{CaCO}_{3}$ efficiently reduce the porosity, refine the pores, and thus making UHSC denser and more homogeneous.
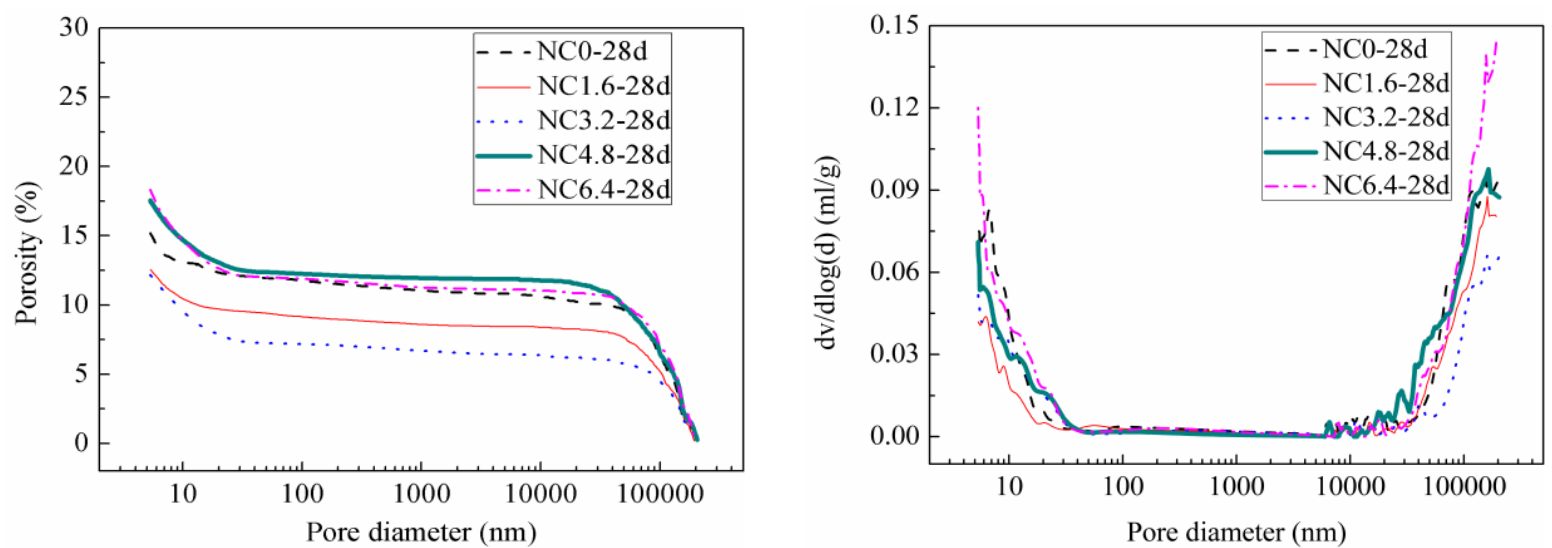

(a) Porosity at $28 \mathrm{~d}$

(b) Differential pore size distribution at $28 \mathrm{~d}$

Fig. 12 Effects of nano- $\mathrm{CaCO}_{3}$ contents on porosity and pore size distribution of UHSC at $28 \mathrm{~d}$

Figure 13 shows the effect of age on porosity and pore size distribution of UHSC containing different nano- $\mathrm{CaCO}_{3}$ contents. It can be observed from Fig. 13(a) that the total porosity decreased with age due to continued hydration. The NC3.2 at $28 \mathrm{~d}$ had a slightly larger total porosity than those at 3 and $7 \mathrm{~d}$. This may be due to the increased volume of pores larger than $5 \mu \mathrm{m}$, as presented in Fig. 13(b). It can be also observed that the peak value on dv/dlog (d) curve reduced gradually with age. The value was $0.08 \mathrm{ml} / \mathrm{g}$ with diameter of $30 \mathrm{~nm}$ at $1 \mathrm{~d}$. At $7 \mathrm{~d}$, it reduced to $0.06 \mathrm{ml} / \mathrm{g}$. With age prolonged to $28 \mathrm{~d}$, it reduced further and shifted to finer pores with diameter of $10 \mathrm{~nm}$ only. This 
corresponds with the results of considerable increase in strength.

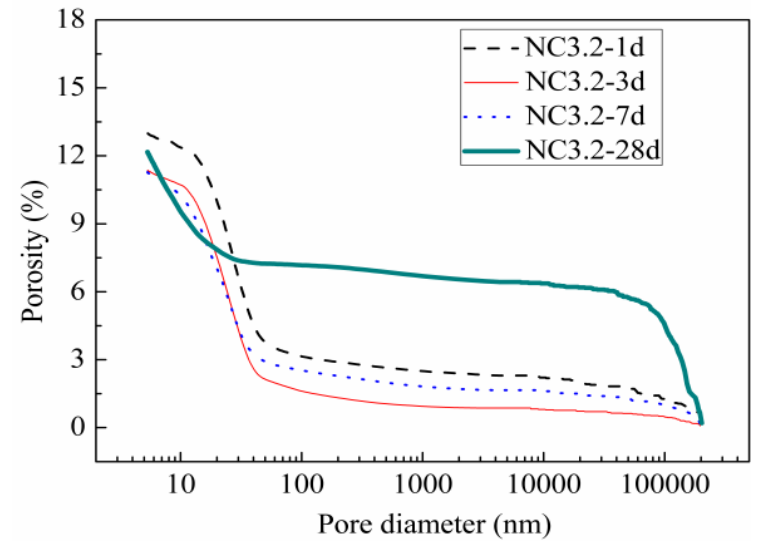

(a) Porosity

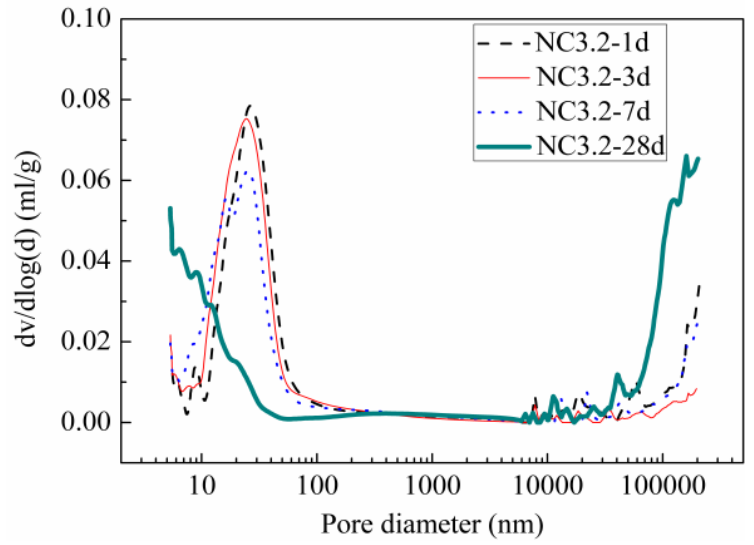

(b) Differential pore size distribution

Fig. 13 Effect of age on porosity and pore size distribution of NC series

In order to further analyze the MIP results, the pores can be classified into five categories, including gel micro-pores $(<10 \mathrm{~nm})$, meso-pores $(10-50 \mathrm{~nm})$, middle capillary pores $(50-100$ $\mathrm{nm})$, large capillary pores $(100-5000 \mathrm{~nm})$, and macro-pores $(>5000 \mathrm{~nm})[41,42]$. These values are summarized in Table 3. It can be seen that the volume fractions of meso-pores and middle capillary pores in UHSC containing nano- $\mathrm{CaCO}_{3}$ were lower than that in the $\mathrm{NC} 0$ reference sample. The total fraction volume of capillary pores in UHSC samples containing nano- $\mathrm{CaCO}_{3}$ was less than $10 \%$, and the volume fraction of middle capillary pores was close to zero regardless of age. Moreover, the gel micro-pores became the dominated pores, a $150 \%$ volume fraction enhancement can be obtained at $28 \mathrm{~d}$ when compared to that without nano- $\mathrm{CaCO}$.

It can be also noted that the fraction volume of large capillary pores decreased with age. This indicated the incorporation of nano- $\mathrm{CaCO}_{3}$ makes the microstructure of UHSC denser and more homogeneous. The pore volume of macro-pores seems to take up a relatively large proportion in all mixtures. This may be due to the large pore size of entrapped air and/or entrained air. 
Table 3 Pore structure characteristics of UHSC with nano- $\mathrm{CaCO}_{3}$

\begin{tabular}{|c|c|c|c|c|c|c|}
\hline \multirow[b]{2}{*}{ NC series } & \multirow{2}{*}{$\begin{array}{c}\text { Total } \\
\text { porosity } \\
(\%)\end{array}$} & \multicolumn{5}{|c|}{ Pore size distribution $(\%)$} \\
\hline & & $\begin{array}{l}<10 \\
(\mathrm{~nm})\end{array}$ & $\begin{array}{c}10 \sim 50 \\
(\mathrm{~nm})\end{array}$ & $\begin{array}{c}50 \sim 100 \\
(\mathrm{~nm})\end{array}$ & $\begin{array}{c}100-5000 \\
(\mathrm{~nm})\end{array}$ & $\begin{array}{c}>5000 \\
(\mathrm{~nm})\end{array}$ \\
\hline $\mathrm{NC} 3.2-1 \mathrm{~d}$ & 12.99 & 15.03 & 2.88 & 0.48 & 14.25 & 67.36 \\
\hline $\mathrm{NC} 3.2-3 \mathrm{~d}$ & 11.37 & 6.29 & 1.35 & 0.24 & 13.21 & 78.91 \\
\hline NC3.2 - $7 \mathrm{~d}$ & 11.28 & 13.22 & 1.53 & 0.45 & 12.79 & 72.01 \\
\hline $\mathrm{NCO}-28 \mathrm{~d}$ & 15.20 & 23.61 & 10.77 & 1.07 & 5.12 & 59.43 \\
\hline $\mathrm{NC} 1.6-28 \mathrm{~d}$ & 12.54 & 65.61 & 1.86 & 0.38 & 7.46 & 24.69 \\
\hline $\mathrm{NC} 3.2-28 \mathrm{~d}$ & 12.17 & 60.81 & 2.28 & 0.70 & 5.87 & 30.34 \\
\hline NC4.8 - $28 d$ & 17.54 & 65.50 & 2.24 & 0.13 & 2.78 & 29.35 \\
\hline NC6.4 - $28 \mathrm{~d}$ & 18.33 & 59.18 & 1.52 & 0.29 & 4.63 & 34.38 \\
\hline
\end{tabular}

404

Figure 14 shows the effects of nano- $\mathrm{SiO}_{2}$ content on porosity and pore size distribution of

UHSC at $1 \mathrm{~d}$. Like the NC series, the total porosity of the NS series decreased with the increase of nano- $\mathrm{SiO}_{2}$ content within a specified dosage of $1.0 \%$. However, as the nano- $\mathrm{SiO}_{2}$ content increased further, the porosity increased. For example, when the nano- $\mathrm{SiO}_{2}$ content increased from 0 to $1.0 \%$, the porosity decreased from $18 \%$ to $13.5 \%$. When the nano- $\mathrm{SiO}_{2}$ content increased from $1.0 \%$ to $2.0 \%$, the porosity increased from $13.5 \%$ to $15 \%$. This might be due to the reduced flowability corresponding to higher nano-SiO 2 content. From Fig. 14 (b), it can also be seen that the peak value 412 become smaller with incorporation of nano- $\mathrm{SiO}_{2}$.
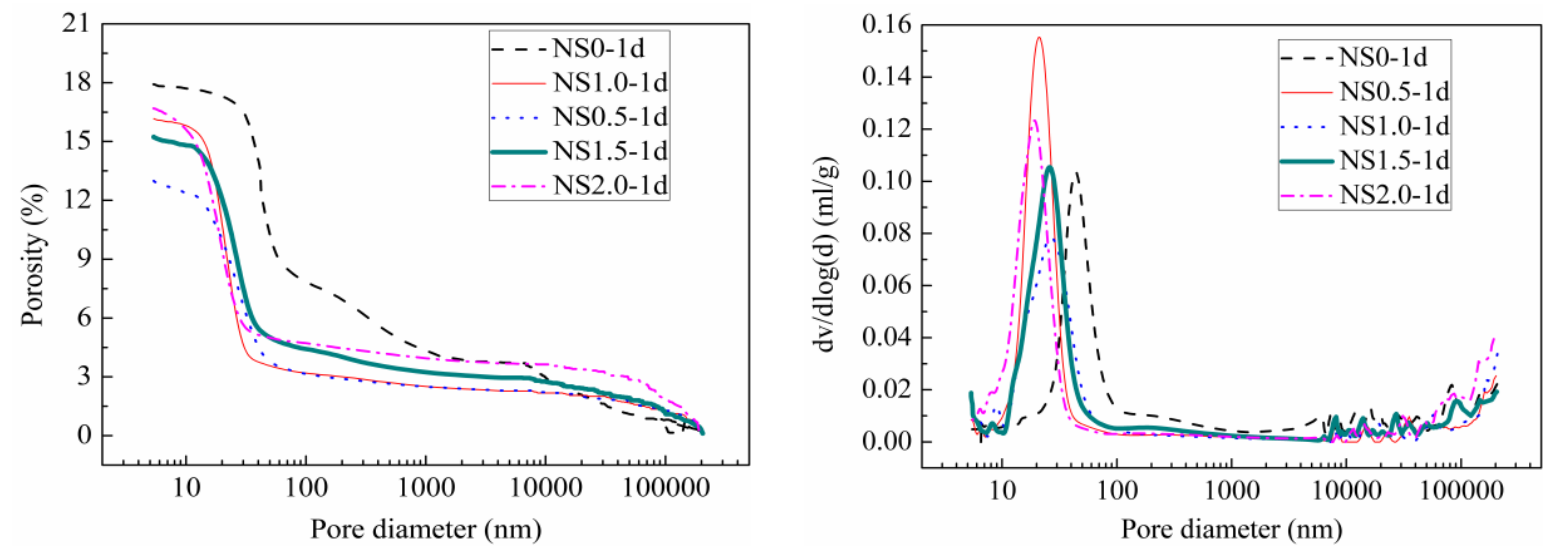

(b) Differential pore size distribution at $1 \mathrm{~d}$ 
terms of age. Due to continued hydration, the total porosity decreased with time but was limited, as shown in Fig. 14 (a). It can be seen from Fig. 14 (b), the peak values on the dv/dlog (d) curve of gradually refined with hydration time.

424

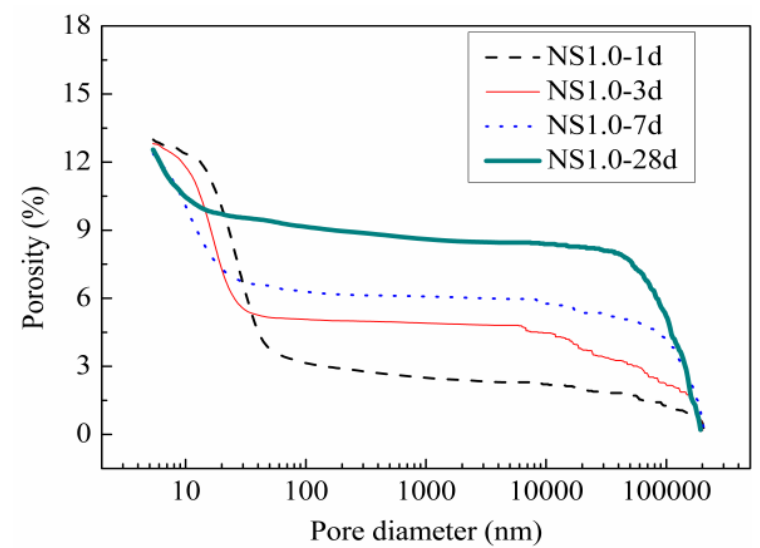

(a) Porosity

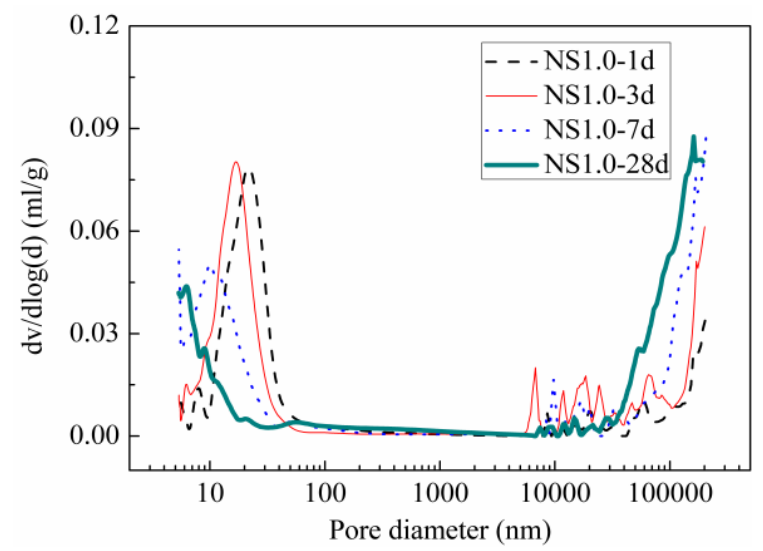

(b) Differential pore size distribution

Fig. 15 Effect of age on porosity and pore size distribution of NS series

Table 4 shows the pore size distribution of UHSC containing nano- $\mathrm{SiO}_{2}$. It can be observed that different from NC series, the NS series at $1 \mathrm{~d}$ had a large amount of meso-pores up to $60 \%$ to $70 \%$ of the total porosity. This mainly depends on their own characteristics such as, size and chemical reactivity. $\mathrm{Nano}-\mathrm{SiO}_{2}$ mainly played its role of pozzolanic reaction at early age, while nano- $\mathrm{CaCO}_{3}$ filled the pores that is close to its own particle size. With the increase of age, the meso-pores remarkable decreased and the gel pores increased, which suggested increased C-S-H content and refined microstructure. In addition, the NS1.0 had a large proportion of macro-pores at $28 \mathrm{~d}$. If nanomaterials cannot be well dispersed, problem associated 
439

440

with aggregation could result in weak zone in the form of voids.

Table 4 Pore structure characteristics of UHSC with nano- $\mathrm{SiO}_{2}$

\begin{tabular}{ccccccc}
\hline \multirow{2}{*}{ NS series } & $\begin{array}{c}\text { Total } \\
\text { porosity } \\
\end{array}$ & \multicolumn{5}{c}{ Pore size distribution $(\%)$} \\
\cline { 3 - 7 } & $\begin{array}{c}<\%) \\
(\mathrm{nm})\end{array}$ & $\begin{array}{c}10 \sim 50 \\
(\mathrm{~nm})\end{array}$ & $\begin{array}{c}50 \sim 100 \\
(\mathrm{~nm})\end{array}$ & $\begin{array}{c}100-5000 \\
(\mathrm{~nm})\end{array}$ & $\begin{array}{c}>5000 \\
(\mathrm{~nm})\end{array}$ \\
\hline NS1.0 - 1 d & 12.99 & 4.75 & 65.93 & 5.07 & 6.77 & 17.48 \\
NS1.0 - 3 d & 12.83 & 8.31 & 51.47 & 0.73 & 1.98 & 37.51 \\
NS1.0 - 7 d & 12.40 & 19.23 & 28.22 & 1.88 & 2.44 & 48.25 \\
NS1.0 - 28 d & 12.55 & 16.71 & 8.41 & 2.10 & 5.34 & 67.44 \\
\hline NS0 - 1 d & 17.92 & 2.52 & 26.52 & 28.03 & 19.61 & 23.32 \\
NS0.5 - 1 d & 16.16 & 2.21 & 75.78 & 2.32 & 5.47 & 14.22 \\
NS1.0 - 1 d & 12.99 & 4.75 & 65.93 & 5.07 & 6.77 & 17.48 \\
NS1.5 - 1 d & 15.46 & 2.83 & 64.41 & 3.98 & 9.32 & 19.46 \\
NS2.0 - 1 d & 18.33 & 6.59 & 63.53 & 1.76 & 6.02 & 22.10 \\
\hline
\end{tabular}

\section{Conclusions}

Based on the results presented in this study, the following conclusions can be drawn:

(1) Both the nano- $\mathrm{CaCO}_{3}$ and nano- $\mathrm{SiO}_{2}$ decreased the flowability and accelerated the heat of hydration of UHSC. The addition of nanomaterials not only shortened the dormant period but also lead to an early appearance of the second peak. For the same content, the use of nano- $\mathrm{CaCO}_{3}$ resulted in greater flowability compared to nano- $\mathrm{SiO}_{2}$.

(2) The optimal dosages for nano- $\mathrm{CaCO}_{3}$ and nano- $\mathrm{SiO}_{2}$ were $1.6 \%$ to $4.8 \%$ and $0.5 \%$ to $1.5 \%$, respectively. If excessive content was added, the strengths were even smaller than that of the reference samples due to agglomeration problem. The nano- $\mathrm{SiO}_{2}$ mainly contributed to the early strength development of UHSC before $7 \mathrm{~d}$, while the nano- $\mathrm{CaCO}_{3}$ led to significant strength increase between 7 and $28 \mathrm{~d}$. However, comparable compressive and flexural strengths of 120 and $23 \mathrm{MPa}$ could be obtained at 28 and $91 \mathrm{~d}$, respectively.

(3) From the TG/DTG results, the $\mathrm{CH}$ content in UHSC series dropped significantly with the increase of nano- $\mathrm{SiO}_{2}$ content, but remained almost unchanged for the nano- $\mathrm{CaCO}_{3}$ system. MIP 
results showed that the porosity and the critical pore size decreased with the increase of hydration time as well as the increase of nanoparticles content to an optimal threshold, beyond which porosity decreased. Both nano- $\mathrm{CaCO}_{3}$ and nano- $\mathrm{SiO}_{2}$ demonstrated nucleation and filling effects and resulted in less porous and more homogeneous structure.

\section{Acknowledgements}

The authors gratefully acknowledge the financial support from the National Science Foundation of China under project Nos. U1305243 and 51378196, as well as the Energy Consortium Research Center of Missouri S\&T under grant No. SMR-1406-09 and the RE-CAST University Transportation Center at Missouri S\&T under grant No. DTRT13-G-UTC45.

\section{References}

[1] Schmidt M, and Ekkehard F. Ultra-high-performance concrete: research, development and application in Europe. ACI Mater J, 2005; 228: 51-78.

[2] Shi CJ, Wu ZM, Xiao JF, Wang DH, Huang ZY, Fang Z. A review on ultra high performance concrete Part I: raw materials and mixture design. Constr Build Mater 2015; 101: 741-751.

[3] Wang DH, Shi CJ, Wu ZM, Xiao JF, Huang ZY, Fang Z. A review on ultra high performance concrete Part II: hydration, microstructure and performance. Constr Build Mater 2015; 96: 368-377.

[4] Sorelli L, Constantinides G, Ulm FJ, Toutlemonde F . The nano-mechanical signature of ultra high performance concrete by statistical nanoindentation techniques. Cem Concr Res, 2008; 38(12): $1447-1456$.

[5] Richardson IG. The nature of CSH in hardened cements. Cem Concr Res, 1999; 29(8): 
$1131-1147$.

[6] Mondal P, Shah SP, Marks L. Nanoscale characterization of cementitious materials. ACI Mater J 2008; 105: 174-179.

[7] Soliman, AM, and Nehdi ML. Effect of drying conditions on autogenous shrinkage in ultra-high performance concrete at early-age. Mater struct, 2011; 44(5): 879-899.

[8] Sanchez F and Sobolev K. Nanotechnology in concrete - a review. Constr Build Mater, 2010; 24(11): 2060-2071.

[9] Ji T. Preliminary study on the water permeability and microstructure of concrete incorporating nano-SiO 2 . Cem Concr Res, 2005; 35(10): 1943-1947.

[10] Li ZH, Wang HF, He S, Lu Y, Wang M. Investigations on the preparation and mechanical properties of the nano-alumina reinforced cement composite. Mater Lett, 2006; 60(3): 356-359.

[11] Li H, Zhang MH, Ou JP. Flexural fatigue performance of concrete containing nano-particles for pavement. Int J Fatig 2007; 29(7): 1292-1301.

[12] Shaikh FUA., Supit SWM. Mechanical and durability properties of high volume fly ash (HVFA) concrete containing calcium carbonate $\left(\mathrm{CaCO}_{3}\right)$ nanoparticles. Constr Build Mater, 2014; 70 : 309-321.

[13] Metaxa ZS, Konsta-Gdoutos MS, Shah SP. Carbon nanotubes reinforced concrete. ACI Special Publication, 2009; 267: 11-20.

[14] Camiletti J, Soliman AM, Nehdi ML. Effects of nano- and micro-limestone addition on early-age properties of ultra-high-performance concrete. Mater Struct, 2013; 46: 881-898.

[15] Shi CJ, Wu ZM, Lv KX, and Wu LM. A review on mixture design methods for self-compacting concrete. Constr Build Mater, 2015; 84: 387-398. 
[16] Bensted J. Further hydration investigations involving Portland cement and the substitution of limestone for gypsum, World Cement, 1983; 14: 383-392.

[17] Wu ZM, Shi CJ. Gao PW, Cao Z, Wang DH. Effects of deicing salts on the salt scaling resistance of concrete. J Mater Civ Eng 2014; 27 (5): 04014160-1-04014160-11.

[18] Rong ZD, Sun W, Xiao HJ, and Jiang G. Effects of nano-SiO $\mathrm{S}_{2}$ particles on the mechanical and microstructural properties of ultra-high performance cementitious composites. Cem Concr Compos, 2015; 56: 25-31.

[19] Ghafari E, Costa H, Júlio E et al. The effect of nanosilica addition on flowability, strength and transport properties of ultra high performance concrete. Mater Design, 2014; 59: 1-9.

[20] Sato T, Beaudoin JJ. Effect of nano- $\mathrm{CaCO}_{3}$ on hydration of cement containing supplementary cementitious materials. Adv Cem Res; 2011; 23: 33-43.

[21] De Weerdt K, Justnes H, Kjellsen KO, Sellevoid EJ. Fly ash-limestone ternary composite cements: synergetic effect at 28 days. Nordic Concr Res; 2010; 42: 51-70.

[22] Péra J, Husson S, Guilhot B. Influence of finely ground limestone on cement hydration. Cem Concr Compos 1999; 21: 99-105.

[23] Hooton RD, Nokke M, Thomas M. Portland-limestone cement: stage of the art report and gap analysis for CSA A 3000, SN303. Toronto: Cement Association of Canada; 2007.

[24] Konsta-Gdoutos MS, Metaxa ZS., Shah SP. Multi-scale mechanical and fracture characteristics and early-age strain capacity of high performance carbon nanotube/cement nanocomposites. Cem Concr Compos, 2010; 32 (2): 110-115.

[25] Chinese national standard. Chinese cement: common portland cement, GB175-2007. Beijing, China, 2007. 
[26] Zu TY. Study on the effects of nano- $\mathrm{CaCO}_{3}$ on the properties of ultra high performance concrete (Master thesis), Hunan University, China, 2013.

[27] Shi CJ, Wang DH, Wu LM and Wu ZM. The hydration and microstructure of ultra high-strength concrete with cement-silica fume-slag binder. Cem Concr Compos, 2015; 61: 44-52.

[28] Wu ZM, Shi CJ, He W, Wu LM. Effects of steel fiber content and shape on mechanical properties of ultra high performance concrete. Constr Build Mater, 2016; 103: 8-16.

[29] Chinese national standard. Test methods for flowability of cement paste, GB2419-2005, Beijing, China, 2005.

[30] Taylor HFW. Cement Chemistry, 2nd ed. Thomas Telford Publishing, London, 1997.

[31] Sato T. Applications of nanotechnology for the sustainable development of cement-based materials, PhD Thesis, University of Ottawa, 171 p. 2006.

[32] De Weerdt K, Haha MB, Saout GL, Justnesa H, Lothenbach B. Hydration mechanisms of ternary Portland cements containing limestone powder and fly ash. Cem Concr Res, 2011; 41 (3): 279-291.

[33] Moon J, Oh JE, Balonis M, Glasser FP, et al.. High pressure study of low compressibility tetracalcium aluminum carbonate hydrates $3 \mathrm{CaO} \cdot \mathrm{Al}_{2} \mathrm{O}_{3} \cdot \mathrm{CaCO}_{3} \cdot 11 \mathrm{H}_{2} \mathrm{O}$. Cem Concr Res, 2012; 42 (1): 105-110.

[34] Damidot D, Stronach S, Kindness A, Atkins M, Glasser FP. Thermodynamic investigation of the $\mathrm{CaO}-\mathrm{Al}_{2} \mathrm{O}_{3}-\mathrm{CaCO}_{3}-\mathrm{H}_{2} \mathrm{O}$ closed system at $25^{\circ} \mathrm{C}$ and the influence of $\mathrm{Na}_{2} \mathrm{O}$. Cem Concr Res, 1994, 24: $563-572$.

[35] Watcharapong W, Thongsanitgarn P, Chindaprasirt P, and Chaipanich A. Thermogravimetry of ternary cement blends. Journal of thermal analysis and calorimetry , 2013, 113(3): 1079-1090. 
[36] Maeshima T, Noma H, Sakiyama M, Mitsuda T. Natural 1.1 and $1.4 \mathrm{~nm}$ tobermorites from Fuka, Okayama, Japan: chemical analysis, cell dimension, ${ }^{29} \mathrm{Si}$ NMR and thermal behavior. Cem Concr Res. 2003; 33: 1515-1523.

[37] Ramezanianpour AA, Ghiasvand E, Nickseresht I, Mahdikhani M, and Moodi F. Influence of various amounts of limestone powder on performance of Portland limestone cement concretes. Cem. Concr. Compos. 2009; 31(10): 715-720.

[38] Ye Q, Zhang ZN, Kong DY, Chen RS. Influence of nano-SiO 2 addition on properties of hardened cement paste as compared with silica fume. Constr Build Mater, 2007; 21(3): 539-545.

[39] Hou PK, Kawashima S, Wang KJ, Corr DJ, Qian JS, Shah SP. Effects of colloidal nanosilica on rheological and mechanical properties of fly ash-cement mortar. Cem Concr Compos, 2013; 35(1): $12-22$.

[40] Ye G. Experimental study and numerical simulation of the development of the microstructure and permeability of cementitious materials. TU Delft, Delft University of Technology, 2003.

[41] Metha PK, Monterio PJM. Concrete, Microstructure, properties and materials, McGraw-Hill, London, 2006.

[42] Zeng Q, Li KF, Chong TF, Dangla P. Pore structure characterization of cement pastes blended with high-volume fly-ash. Cem Concr Res, 2012; 42(1): 194-204. 


\section{List captions}

Table 1 Chemical composition and physical properties of raw materials

Table 2 Mixture proportions of UHSC

Table 3 Pore structure characteristics of UHSC with nano- $\mathrm{CaCO}_{3}$

Table 4 Pore structure characteristics of UHSC with nano- $\mathrm{SiO}_{2}$ 


\section{Figure captions}

Fig. 1 Morphogy of nano-particles

Fig. 2 Mixing and curing procedure of UHSC

Fig. 3 Mini slump flow of UHSC with different nano- $\mathrm{CaCO}_{3}$ and nano-SiO $\mathrm{S}_{2}$ contents

Fig. 4 Effects of nano- $\mathrm{CaCO}_{3}$ and nano-SiO 2 contents on heat evolution rate of UHSC

Fig. 5 Effects of nano- $\mathrm{CaCO}_{3}$ contents on compressive and flexural strengths of UHSC

Fig. 6 Effect of different nano-SiO 2 contents on compressive and flexural strengths of UHSC

Fig. $7 \mathrm{TG}$ and DTG curves of UHSC with different nano- $\mathrm{CaCO}_{3}$ contents at $28 \mathrm{~d}$

Fig. 8 TG and DTG curves of NS3.2 at different ages

Fig. 9 TG and DTG curves of UHSC with different nano-SiO 2 contents at $28 \mathrm{~d}$

Fig. 10 TG and DTG curves of NS1.0 at different ages

Fig. 11 Amount of $\mathrm{CH}$ formed in UHSC samples with age

Fig. 12 Effects of nano- $\mathrm{CaCO}_{3}$ contents on porosity and pore size distribution of UHSC at $28 \mathrm{~d}$

Fig. 13 Effect of age on porosity and pore size distribution of NC series

Fig. 14 Effects of nano- $\mathrm{SiO}_{2}$ contents on porosity and pore size distribution of UHSC at $1 \mathrm{~d}$

Fig. 15 Effect of age on porosity and pore size distribution of NS series 